\title{
Active Participation of the IEM at the 45th Conference of the Association for Spanish and Portuguese Historical Studies
}

\section{Alicia Miguélez Cavero}

\section{(2) OpenEdition}

\section{Journals}

Electronic version

URL: http://journals.openedition.org/medievalista/1549

DOI: 10.4000/medievalista.1549

ISSN: 1646-740X

Publisher

Instituto de Estudos Medievais - FCSH-UNL

\section{Electronic reference}

Alicia Miguélez Cavero, "Active Participation of the IEM at the 45th Conference of the Association for Spanish and Portuguese Historical Studies », Medievalista [Online], 17 | 2015, Online since 01 June 2015, connection on 23 September 2020. URL : http://journals.openedition.org/medievalista/1549 DOI : https://doi.org/10.4000/medievalista.1549

\section{(c) (7) 8}

Mediavalista está licenciado com uma Licença Creative Commons - Atribuição-NãoComercial 4.0 Internacional. 
Revista ISSN 1646-740X

Medievalista onine

Título: Active Participation of the IEM at the 45th Conference of the Association for Spanish and Portuguese Historical Studies

Autor(es): Alicia Miguélez Cavero

Universidade: Universidade Nova de Lisboa

Faculdade e Departamento / Unidade de Investigação: IEM - FCSH/UNL

Código Postal: 1069-061

Cidade: Lisboa

País: Portugal

Contacto: amiguelez@fcsh.unl.pt

Fonte: Medievalista [Em linha]. Direc. José Mattoso. Lisboa: IEM.

Disponível em: http://www2.fcsh.unl.pt/iem/medievalista/

ISSN: 1646-740X

Data do texto: 16 de Setembro de 2014 


\title{
Active Participation of the IEM at the 45 th Conference of the Association for Spanish and Portuguese Historical Studies
}

\author{
Alicia Miguélez Cavero
}

The Association for Spanish and Portuguese Historical Studies promotes interest in the scholarly study of Spain and Portugal through History and related disciplines. Several activities and initiatives are thus organized and planned every year to achieve this goal. They include a newsletter that focuses on news of society in general, professional conferences and events of interest to Iberian historians, and activities of the membership; the publication of the Bulletin for Spanish and Portuguese Historical Studies; a programme to provide members with small subventions for regional and local gatherings; three prizes for excellence in scholarship in Iberian history by scholars; and the organization of an annual conference, which is organized in a different place every year.

The 45th Annual Conference took place in Modena (Italy) on June 26-29 2014, thanks to the support and organization of the Università di Modena e Reggio Emilia (Dipartimento di Studi linguistici e culturali), the Instituto di Studi Storici Gaetano Salvamini (Torino) and the Redazione di “Spagna Contemporanea”.

The IEM participated actively in the Conference and up to four sessions had five papers delivered by integrated members of the Institute, both seniors and juniors, and from several disciplines. Dr. Maria João Branco participated in Session 39, devoted to analyze the relationship between chancery and ecclesiastics in Medieval Portugal, a panel organized within the scope of the DEGRUPE Project (PTDC/EPHHIS/4964/2012), sponsored by FCT/MCTES. Her contribution, under the title "An 
ecclesiastic as chancellor of three Kings? The case of Julião Pais”, dealt with the multiple roles played by Julião Pais in the chancery of the first Portuguese Kings as well as in the town of Coimbra and near the jurists which started to flock to the King's court at precisely his time in office. Also a member of the Project DEGRUPE, and equally sponsored by the above mentioned FCT/MCTES, Dr. Francisco Díaz Marcilla participated in Session 63, where several aspects on philosophers, chroniclers and monarchies were discussed. The paper delivered by Dr. Díaz Marcilla, under the title “Clero laudante: el uso político de la poesía por los clérigos en la conformación y consolidación de las monarquías peninsulares (1370-1450)” provided information on how clerks used poetry as a political weapon during the consolidation process of Iberian monarchies.

Dr. Catarina Barreira, on her part, joined Session 70, an interdisciplinary panel where several issues on churches and monasteries in Medieval Galicia and Portugal were addressed. The paper delivered by Dr. Barreira, "Gazophylacium Domini or the Presence of Peter Lombard's Sentences in a Portuguese Cistercian Abbey”, revolved around the Alcobaça Abbey and its rich medieval library funds.

Finally, Drs. Ana Lemos and Alicia Miguélez Cavero participated in Session 75, devoted to artistic routes, sources and circulation of religious imagery. Dr. Ana Lemos, whose contribution was “Quando a História da Arte e as Ciências se encontram: o IL 15 e o IL 19, dois Livros de Horas da Biblioteca Nacional de Portugal”, brought the audience's attention to how important are those interdisciplinary studies carried out by scholars from the Humanities and Exact Sciences, and explained the results of a crossscience project on two Books of Hours today preserved at the National Library of Portugal. Dr. Alicia Miguélez, who is currently working on Beatus manuscripts, delivered the paper "Looking for a Lost Archetype. The Iconographic Sources of Beatus Manuscripts”, providing new facts and hypotheses on the Beatus pictorial tradition and its archetype.

The Annual Conference of the Association for Spanish and Portuguese Historical Studies turned thus into one of the main 2014 international events in which the IEM has disseminated the results of the research conducted by its members in several fields. The warm welcome received by the ideas and hypotheses proposed by the members of the IEM has again demonstrated the high scientific level the IEM has achieved in the past 
recent years, and the important role it is playing not only in events relating to Medieval Studies specifically, but also in the Humanities in general.

\section{COMO CITAR ESTE ARTIGO}

\section{Referência electrónica:}

MIGUÉLEZ CAVERO, Alicia - “Active Participation of the IEM at the 45th Conference of the Association for Spanish and Portuguese Historical Studies”.

Medievalista [Em linha]. № 17 (Janeiro - Junho 2015). [Consultado 01.01.2015].

Disponível em http://www2.fcsh.unl.pt/iem/medievalista/MEDIEVALISTA17/ cavero1712.html

ISSN 1646-740X.

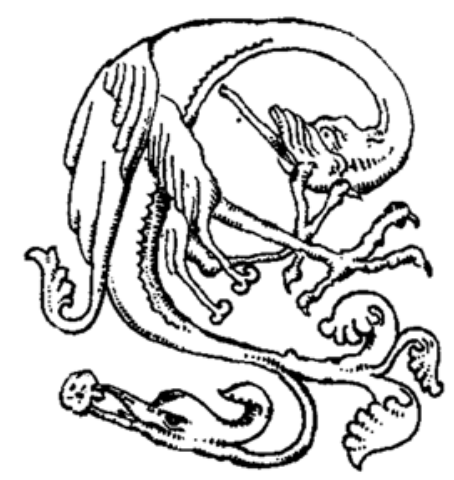

